ROCZNIKI TEOLOGICZNE

Tom LXVIII, zeszyt $10-2021$

DOI: https://doi.org/10.18290/rt.216810.9

KATARZYNA STANKIEWICZ

ANNA ŻUREK

\title{
WYCHOWANIE DWUJEZYYCZNE W RODZINIE POLONIJNEJ W NIEMCZECH. PERSPEKTYWA DRUGIEGO POKOLENIA EMIGRANTÓW
}

\author{
BILINGUAL EDUCATION IN A POLISH FAMILY IN GERMANY. \\ THE PERSPECTIVE OF THE SECOND GENERATION OF MIGRANTS
}

\begin{abstract}
A b s t r a c t. The aim of the article is to present the process of bilingual education in a Polish diaspora family living in Germany on the basis of research conducted among adult representatives of the second generation of migrants. The background for the presentation of the research results will be the discussion of the specificity of the functioning of Polish diaspora families in Germany and the basics of the theory of bilingual education in an interdisciplinary approach. The review of the literature on the subject and the analysis of the research results will allow for the formulation of recommendations in the field of developing a child's full bilingualism and nurturing relationships with Polish and Polish culture through appropriate language education at home.
\end{abstract}

Keywords: bilingual education; bilingualism; Polish family in Germany; migration, Polish language.

Wychowanie dziecka na emigracji niesie ze sobą wiele wyzwań w zakresie przekazywania języka, kultury i tradycji kraju pochodzenia, jak również integracji rodziny ze społeczeństwem państwa przyjmującego. Jednym z obszarów

Dr Katarzyna Stankiewicz - Instytut Pedagogiki, Uniwersytet Kardynała Stefana Wyszyńskiego w Warszawie; adres do korespondencji: ul. Wóycickiego1/3, 01-938 Warszawa; e-mail: katarzyna.stankiewicz@uksw.edu.pl; ORCID: https://orcid.org/0000-0003-0554-4261

Dr hab. ANNA ŻUREK - Instytut Filologii Polskiej, Uniwersytet Wrocławski; adres do korespondencji: pl. Nankiera 15b, 50-140 Wrocław; e-mail: anna.zurek@uwr.edu.pl; ORCID: https://orcid.org/0000-0003-4216-3636. 
istotnych podczas procesu wychowania jest wspieranie rozwoju językowego dziecka, ściśle powiązanego z kształtowaniem jego tożsamości społecznej i kulturowej. Świadomie prowadzone wychowanie dwujęzyczne w sytuacji emigracji rodziny może wspierać strategię integracji społecznej w nowym miejscu, pozwalając jednocześnie na zachowanie języka i kultury kraju pochodzenia. Na emigracji naturalna dwujęzyczność, zazwyczaj polegająca na nabywaniu języka ojczystego w środowisku domowym i poznawaniu drugiego języka przez dzieci podczas edukacji przedszkolnej i szkolnej, jest niepełna i ograniczona do kontekstów codziennej komunikacji oraz kodu mówionego w języku kraju pochodzenia. Rodzinę możemy traktować jako wspólnotę kulturową oraz środowisko kulturowe, które wprowadza dziecko w świat języka i kultury na drodze przekazu międzypokoleniowego ${ }^{1}$. Celowo podjęte w środowisku rodzinnym wychowanie dwujęzyczne służy wykształceniu pełnej, zrównoważonej dwujęzyczności, a co za tym idzie sprzyja przekazowi polskiej kultury. Jednocześnie otwiera ono przed drugim pokoleniem emigrantów możliwość wykorzystania potencjału, jakim jest dwujęzyczność i dwukulturowość, budowania mostów między dwiema kulturami, z którymi mają kontakt, podjęcia dalszej edukacji czy też pracy zawodowej w kraju rodziców, a nawet powrotu do niego, osiedlenia się tam w przyszłości - bez poczucia obcości.

Niemcy - ze względu na bliskość geograficzną oraz poziom rozwoju gospodarczego - są popularnym wśród Polaków krajem tymczasowych migracji zarobkowych oraz emigracji ${ }^{2}$, z długą tradycją funkcjonowania ruchów polonijnych, skoncentrowanych między innymi wokół sobotnich szkół polonijnych funkcjonujących przy Kościele katolickim, a dokładnie przy Polskiej Misji Katolickiej ${ }^{3}$. Mimo długiej tradycji migracji do Niemiec i dużej liczebnie Polonii w tym kraju, wciąż brakuje systemowego wsparcia i ułatwień dla polskich zabiegów podtrzymywania tożsamości narodowej na emigracji ze strony państwa niemieckiego. Zgodnie z zapisami Traktatu między Rzeczypospolita Polska a Republika Federalna Niemiec o dobrym sqsiedztwie i przyjaznej wspótpracy z 17 czerwca 1991 roku osoby, które posiadają obywatelstwo niemieckie i są polskiego pochodzenia, mają prawo „do swobodnego

\footnotetext{
${ }^{1}$ Stanisław Kawula, „Rodzina jako grupa i instytucja opiekuńczo-wychowawcza”, w Pedagogika rodziny. Obszary i panorama problematyki, red. Stanisław Kawula, Józefa Bragiel, Andrzej W. Janke (Toruń: Wydawnictwo Adam Marszałek, 1998), 57.

2 Barbara Cieślińska, „Niemcy bliskie i dalekie w świetle doświadczeń migracyjnych mieszkańców północno-wschodniej Polski”, Pogranicze. Studia Społeczne 18(2011): 101-103.

${ }^{3}$ Aleksandra Trzcielińska-Polus, „Polska Misja Katolicka w Niemczech - jej rola w integracji środowiska polskiego", Ślaskie Studia Historyczno-Teologiczne 37(2004): 22-30.
} 
wyrażania, zachowania i rozwijania swej tożsamości etnicznej, kulturalnej, językowej i religijnej bez jakiejkolwiek próby asymilacji wbrew ich woli" ${ }^{4}$. Współczesne środowiska emigracyjne w Niemczech wciąż nie mają oficjalnego statusu mniejszości narodowej, formalnie traktowane sa jako „grupa etniczna" z ograniczonymi prawami ${ }^{5}$. Dominująca wydaje się ciągle strategia asymilacyjna państwa niemieckiego wobec obcokrajowców ${ }^{6}$. Wychowanie dwujęzyczne w tej sytuacji staje się dla rodzin polonijnych tym większym wyzwaniem.

Celem tego artykułu jest przedstawienie wychowania dwujęzycznego oraz jego uwarunkowań i efektów w rodzinie polonijnej, mieszkającej w Niemczech, na podstawie badań przeprowadzonych wśród dorosłych przedstawicieli drugiego pokolenia emigrantów. Tłem dla prezentacji wyników badań będzie omówienie specyfiki funkcjonowania rodzin polonijnych w Niemczech oraz podstaw teorii wychowania dwujęzycznego w ujęciu interdyscyplinarnym językoznawczym i pedagogicznym. Przegląd literatury przedmiotu oraz analiza wyników badań pozwolą na sformułowanie rekomendacji w zakresie rozwijania pełnej dwujęzyczności dziecka oraz pielęgnowania związków z Polską i polską kulturą poprzez odpowiednie wychowanie językowe w domu rodzinnym.

\section{DWUJĘZYCZNOŚĆ - UJĘCIE TEORETYCZNE}

Zjawisko bilingwizmu od lat cieszy się zainteresowaniem badaczy różnych dyscyplin. Ze względu na swój interdyscyplinarny charakter analizowane jest z perspektywy językoznawczej, pedagogicznej, psychologicznej, socjologicznej czy kulturowej. W zależności od przyjętego ujęcia dwujęzyczność może być definiowana na różne sposoby. Jak zauważa Anna Żurek: „Definicje bilingwizmu indywidualnego oscylują między maksymalistycznym a minimalistycznym podejściem. Przedstawicielem pierwszego jest choćby Leonard Bloomfield, który za-

\footnotetext{
${ }^{4}$ Traktat między Rzeczypospolita Polska a Republika Federalna Niemiec o dobrym sqsiedztwie i przyjaznej wspótpracy, podpisany w Bonn dnia 17 czerwca 1991 r., Dz.U. 1992, nr 14, poz. 56, 198.

${ }^{5}$ Łukasz Ryszka, „Rola i znaczenie przekazu pokoleniowego w krzewieniu świadomości narodowo-kulturowej na przykładzie współczesnej Polonii w Niemczech”, Wychowanie w Rodzinie 9(1/2014): 130.

${ }^{6}$ Katarzyna Stankiewicz i Anna Żurek, Ukryty program nauczania polskiego i niemieckiego jako języków obcych. Konteksty kulturowe (Łask: Oficyna Wydawnicza Leksem, 2014), 56-58.
} 
kłada pełną biegłość w obu językach [...]. Reprezentanci podejścia minimalistycznego uznają dwujęzyczność za praktykę naprzemiennego użycia obu języków [...] lub regularne używanie dwóch języków [...]. W ostatnim ujęciu bycie osobą dwujęzyczną to zdolność przechodzenia z jednego języka na drugi w zależności od sytuacji komunikacyjnej przy założeniu asymetrycznej kompetencji w tych językach [...]"7. Szczególnie przydatna wydaje się ostatnia definicja, która odnosi się do środowisk polonijnych posługujących się dwoma językami w zależności od potrzeb. W funkcjonalnym ujęciu przy definiowaniu bilingwizmu nadrzędną rolę pełni kryterium użycia obu języków, nie zaś stopnia ich opanowania (tj. osiągniętej biegłości językowej w obu językach).

W zależności od sposobu przyswajania języka drugiego wyróżnia się bilingwizm naturalny i sztuczny. Pierwszy dotyczy osób, które od najmłodszych lat przyswajają język, drugi w naturalnym środowisku, dzięki wychowaniu w rodzinie dwujęzycznej. Drugi zaś obejmuje naukę języka drugiego w warunkach sformalizowanych, jak np. na lekcjach w szkole czy kursach językowych ${ }^{8}$.

Biorąc pod uwagę kryterium wieku przyswojenia danego języka, wyróżnia się dwujęzyczność wczesną i późną. Pierwszy typ obejmuje okres od momentu narodzin do wczesnego dzieciństwa. Wyróżnia się tutaj dwujęzyczność równoczesną (gdy dana jednostka przyswaja oba języki w tym samym czasie, przed osiagnnięciem trzeciego roku życia) i sekwencyjną (gdy przyswajanie drugiego języka rozpoczyna się po ukończeniu 3 lat). Bilingwizm późny dotyczy sposobu nabywania języka drugiego przez dzieci powyżej 12 roku życia, młodzież lub osoby dorosłe ${ }^{9}$. Dwujęzyczność wczesnodziecięca często pozwala na wszechstronny rozwój obu systemów językowych, z kolei dwujęzyczność późna nie gwarantuje osiągnięcia poziomu biegłości językowej bliskiej rodzimym użytkownikom, zwykle jeden z języków zostaje na niższym poziomie ${ }^{10}$.

Kolejny podział dwujęzyczności wiąże się ze stopniem opanowania obu języków. Gdy dana osoba osiąga zbliżoną kompetencję językową w obu kodach komunikacyjnych, wówczas można mówić o bilingwizmie zrównoważonym (peł-

\footnotetext{
${ }^{7}$ Anna Żurek, Strategie komunikacyjne osób dwujęzycznych. Na przykładzie polszczyzny odziedziczonej w Niemczech (Kraków: Towarzystwo Autorów i Wydawców Prac Naukowych Universitas, 2018), 35.

${ }^{8}$ Katarzyna Wróblewska-Pawlak, Język, tożsamość, imigracja: o strategiach adaptacyjnych Polaków zamieszkatych we Francji w latach osiemdziesiatych XX wieku (Warszawa: Uniwersytet Warszawski, 2004), 70.

${ }^{9}$ Wróblewska-Pawlak, Język, tożsamość, imigracja, 69.

${ }^{10}$ Agnieszka Pędrak, „Wielowymiarowość dwujęzyczności dzieci (w kontekście emigracji)”, Spoteczeństwo. Edukacja. Język 7(2018): 155-156.
} 
nym). Tego typu bilingwizm występuje stosunkowo rzadko ${ }^{11}$. O wiele częściej mamy do czynienia z dwujęzycznością niezrównoważoną (niepełną), oznaczającą nierównomierny stopień zaawansowania obu języków. Osoby dwujęzyczne, wychowane w warunkach emigracji, osiagają zwykle większą biegłość w języku kraju osiedlenia, nie zaś pochodzenia ${ }^{12}$. Z językowego i kulturowego punktu widzenia idealny jest natomiast bilingwizm zrównoważony, oznaczający równomierny rozwój kompetencji w obu językach ${ }^{13}$.

Dzieci pierwszej generacji emigrantów należą do pokolenia polonijnego. Ze względu na edukację szkolną w kraju osiedlenia poddają się łatwiej procesowi naturalizacji w nowym kręgu językowo-kulturowym, rozwijają dwujęzyczność i dwukulturowość, szybciej integrują się z nowym społeczeństwem, a tym samym wykazują słabszą więź (niż pokolenie rodziców) z językiem i kulturą kraju pochodzenia ${ }^{14}$.

\section{WYCHOWANIE DWUJĘZYCZNE W RODZINIE POLONIJNEJ - PRZEGLĄD BADAŃ}

Należy wskazać na zasadnicze rozróżnienie między dwoma sytuacjami nabywania przez dziecko dwujęzyczności - poprzez funkcjonowanie w rodzinie mieszanej, gdzie rodzice mówią różnymi językami i oba te języki przekazują dziecku, oraz poprzez wychowanie w środowisku rodziców imigrantów pochodzących z tej samej kultury i o tym samym języku ojczystym, odmiennym od języka otoczenia, w którym dziecko z reguły podejmuje edukację szkolną ${ }^{15}$. O wychowaniu dwujęzycznym możemy mówić, jeżeli wychowaniu dziecka towarzyszą dwa języki, niezależnie od uwarunkowań sytuacji, w której się ono znajduje ${ }^{16}$. Osobami oddziałującymi w tym przypadku na wychowanka mogą być nie tylko rodzice, ale również dziadkowie, inni krew-

\footnotetext{
${ }^{11}$ Ewa Lipińska, Język ojczysty, język obcy, język drugi. Wstęp do badań dwujęyczności (Kraków: Wydawnictwo Uniwersytetu Jagiellońskiego, 2003), 109.

12 Żurek, Strategie komunikacyjne osób dwujęzycznych, 124.

${ }^{13}$ Ewa Lipińska, Polskość w Australii - o dwujęzyczności, edukacji i problemach adaptacyjnych Polonii na antypodach (Kraków: Wydawnictwo Uniwersytetu Jagiellońskiego, 2013), 163.

${ }^{14}$ Stanisław Dubisz, ,Z metodologii badań języka środowisk polonijnych”, Poradnik Językowy 5(1983), 295.

${ }^{15}$ Katarzyna Wróblewska-Pawlak, „Naturalna dwujęzyczność, czyli o dwujęzycznym wychowaniu dzieci”, Języki Obce w Szkole 1(2013): 89.

${ }^{16}$ Magdalena Olpińska-Szkiełko, Wychowanie dwujezyczne w przedszkolu (Warszawa: Wydawnictwo Naukowe IKLA UW, 2013), 77.
} 
ni i znajomi - w przypadku polskiego, oraz szkoła, rówieśnicy i otoczenie przy języku kraju osiedlenia. Warto zauważyć, że również w sytuacji rodziców imigrantów nie mamy do czynienia wyłącznie z rozwijaniem dwujęzyczności dziecka typu dom-szkoła, ponieważ w toku komunikowania się w środowisku domowym wykorzystywane są również - chociażby okazjonalnie elementy kodu językowego kraju osiedlenia. Jego użycie jest niezbędne, np. przy wspólnym odrabianiu lekcji czy uczestnictwie w imprezach szkolnych, kontaktach z osobami z otoczenia nieznającymi polskiego itp., które składają się na codzienne funkcjonowanie rodziny na emigracji ${ }^{17}$.

Temat wychowania dwujęzycznego podejmuje Jadwiga Cieszyńska w swojej monografii Dwujęzyczność, dwukulturowość - przekleństwo czy bogactwo? O poszukiwaniu tożsamości Polaków w Austrii ${ }^{18}$. Praca ma charakter empiryczny. Autorka przyjęła ujęcie interdyscyplinarne i powiązała kwestie nabywania języka z rozwojem tożsamościowym. Uwzględniła przy tym tematykę wychowania dwujęzycznego. Cieszyńska w części teoretycznej monografii szeroko przedstawia i analizuje dostępną literaturę przedmiotu. Wskazuje na problemy związane z niedostateczną znajomością przez rodziców języka otoczenia, w związku z którą nie są oni w stanie być wsparciem dla swoich dzieci w edukacji szkolnej. Sytuacja migracji, zdaniem autorki monografii, zmienia relacje między dzieckiem a rodzicem. Dziecko, szybciej przyswajając język kraju osiedlenia, często wchodzi w rolę tłumacza. „Bezradność i niedoskonałość językowa rodziców jest zagrożeniem dla dziecka"19 - zauważa Cieszyńska. Może to skutkować podważeniem rodzicielskiego autorytetu.

Na temat roli wychowania dwujęzycznego dzieci pisała m.in. Agnieszka Stępkowska, która uważa, że „świadomie prowadzona polityka rodzinna par mieszanych językowo przynosi pożądane skutki w zakresie pełnej dwujęzyczności ich dzieci" "20. Aktywne opanowanie obu języków rodziców sprzyja procesowi społecznej socjalizacji i kulturowej adaptacji dzieci. To wszystko jest możliwe dzięki pozytywnemu nastawieniu rodziców wobec dwujęzyczności i dwukulturowości swoich dzieci, podtrzymywaniu ich motywacji języ-

\footnotetext{
17 Wróblewska-Pawlak, „Naturalna dwujęzyczność, czyli o dwujęzycznym wychowaniu dzieci”, 88-97.

18 Jadwiga Cieszyńska, Dwujęzyczność, dwukulturowość - przekleństwo czy bogactwo? O poszukiwaniu tożsamości Polaków w Austrii (Kraków: Wydawnictwo Naukowe Akademii Pedagogicznej, 2006).

${ }^{19}$ Cieszyńska, Dwujęzyczność, dwukulturowość, 76.

20 Agnieszka Stępkowska, „Rodzinna polityka dwujęzyczności w Polsce na wybranym przykładzie”, Scripta Neophilologica Posnaniensia 17(2017): 329.
} 
kowej oraz konsekwentnej strategii wspierania języka mniejszości w środowisku domowym.

Warto wskazać na zasygnalizowany już w literaturze przedmiotu związek między podejściem rodziców do rozwijania wielojęzyczności ich dzieci a przyjętą przez rodzinę strategią akulturacyjną. W takim ujęciu najbardziej sprzyjającą zrównoważonemu bilingwizmowi drugiego pokolenia emigrantów strategią jest integracja, zakładająca otwarcie zarówno na kulturę pochodzenia, jak również kulturę kraju osiedlenia ${ }^{21}$. Język umożliwia dostęp do kultury i tradycji. Dwujęzyczność otwiera zatem na obie kultury, w których może poruszać się dziecko czy też młody człowiek z rodziny polonijnej ${ }^{22}$.

Problematyka wychowania dwujęzycznego w rodzinie polonijnej, szczególnie $\mathrm{w}$ odniesieniu do bilingwizmu polsko-niemieckiego, jak dotąd stanowiła rzadki przedmiot rozważań naukowych. W jednej ze swoich najnowszych prac Hanna Pułaczewska zaprezentowała różnorodne postawy rodzicielskie wobec przekazywania języka polskiego dzieciom wychowywanym w Niemczech ${ }^{23}$. Jej badania - przeprowadzone w latach 2014-2016 - ukazują perspektywę polskojęzycznych matek nastolatków w wieku od 13 do 18 lat wychowujących się w Ratyzbonie i wpisują się w nurt badań nad tzw. rodzinną polityką językową. Autorka monografii Wychowanie do jezyka polskiego w Niemczech na przykładzie Ratyzbony. Dwujęzyczność dzieci z perspektywy rodziców wyróżniła sześć postaw rodzicielskich, które w znacznym stopniu decyduja o przekazywaniu (bądź nieprzekazywaniu) języka polskiego. Należy do nich postawa autonomistyczna, opiekuńcza, relacjonistyczna, kolektywistyczna, patriotyczna i ekonomistyczna. Pierwsza z nich uwzględnia preferencje dziecka co do sposobów i zakresu komunikowania się po polsku. Kolejna rezygnuje $\mathrm{z}$ przekazywania języka polskiego, jeśli jest to niezgodne $\mathrm{z}$ interesem dziecka. Postawa relacjonistyczna jako wartość nadrzędną uznaje relację rodzica z dzieckiem, a tym samym podkreśla rolę języka rodzimego jako bardziej naturalnego i emocjonalnego. W postawie kolektywistycznej język polski stanowi narzędzie podtrzymujące więzi rodzinne. Postawa patriotyczna służy identyfikacji narodowo-etnicznej, natomiast ekonomistyczna traktuje

${ }^{21}$ Lipińska, Polskość w Australii, 29.

${ }^{22}$ Katarzyna Stankiewicz i Anna Żurek. „Poradnictwo pedagogiczne w zakresie dwujęzyczności. Wsparcie rodziny na emigracji”, w Poradnictwo rodzinne na emigracji. Teoria i praktyka, red. Józef Młyński, Władysław Szewczyk (Warszawa: Wydawnictwo UKSW, 2021), 161-175.

${ }^{23}$ Hanna Pułaczewska, Wychowanie do jezzyka polskiego $w$ Niemczech na przykładzie Ratyzbony: dwujęzyczność dzieci z perspektywy rodziców (Łódź: Wydawnictwo Primum Verbum, 2017). 
język polski jako narzędzie komunikacji ${ }^{24}$. Wymienione przez Hannę Pułaczewską postawy aksjologiczne wobec przekazywania (lub nie) języka polskiego w rodzinie polonijnej przenikają się nawzajem, a z czasem ulegaja przekształceniom w zależności od wieku dziecka i jego aktualnych potrzeb. Autorka wskazuje na raczej negatywny klimat społeczny niesprzyjający pielęgnacji języków innych niż niemiecki. o którym wspominają jej badani. Wychowanie dwujęzyczne dziecka, pochodzącego z polskiej rodziny, spotykało się z krytyczną oceną różnych środowisk, a mianowicie wychowawców przedszkolnych, nauczycieli, niemieckojęzycznych rodziców i rówieśników. Dwujęzyczność była przez nich postrzegana jako zjawisko hamujące właściwy rozwój poznawczy dziecka ${ }^{25}$.

\section{WYCHOWANIE DO NIEPEŁNEJ DWUJEZZYCZNOŚCI - ANALIZA WYNIKÓW BADAŃ WŁASNYCH}

Na potrzeby niniejszej pracy przeanalizowano 20 wywiadów przeprowadzonych z dorosłymi osobami dwujęzycznymi, które wychowywały się w rodzinach polonijnych w Niemczech ${ }^{26}$. Dodatkowych informacji dostarczył kwestionariusz osobowy. Jak wynika z analizy uzyskanych danych, część badanych wyjechała z Polski wraz z rodzicami między 1 a 4 rokiem życia (7 osób), większość zaś urodziła się już w Niemczech (13 osób).

Badani to osoby wczesnodwujęzyczne, dla których język polski stanowi domowy kod komunikacyjny, język niemiecki stał się natomiast podstawowym narzędziem porozumiewania się, zarówno w sytuacjach oficjalnych (na studiach, w pracy), jak i nieoficjalnych (np. z rodzeństwem czy rówieśnikami). Chociaż przyswoili oni język polski, w pierwszej kolejności, na co dzień, posługują się językiem niemieckim traktowanym jako język funkcjonalnie silniejszy. Ich dwujęzyczność ma zatem charakter niezrównoważony (niepełny), zdecydowana większość posługuje się polszczyzną poniżej poziomu

\footnotetext{
${ }^{24}$ Tamże, 133-166.

25 Tamże, 83-84.

${ }^{26} \mathrm{~W}$ artykule wykorzystano dane zebrane w ramach polsko-niemieckiego projektu pt. Lingwistyczne i glottodydaktyczne aspekty niepełnej polsko-niemieckiej dwujęzyczności, realizowanego w latach 2012-2014 przez Uniwersytet Wrocławski we współpracy z Uniwersytetem Alberta Ludwika we Fryburgu Bryzgowijskim. Więcej o całym przedsięwzięciu w publikacji: Juliane Besters-Dilger, Anna Dąbrowska, Grzegorz Krajewski i Anna Żurek (red.), Utrata $i$ odzyskiwanie języka polskiego. Językoznawcze i glottodydaktyczne aspekty niepetnej polsko-niemieckiej dwujęzyczności (Łask: Oficyna Wydawnicza Leksem, 2016).
} 
średnio zaawansowanego (B2). Wśród badanych reprezentantów pokolenia polonijnego dominują studenci i osoby $\mathrm{z}$ wykształceniem wyższym, w momencie przeprowadzania wywiadów mieli oni od 21 do 31 lat (urodzeni w latach 1983-1993).

Na użytek tego artykułu sformułowano następujący problem badawczy: Jak przebiega wychowanie dwujęzyczne oraz jakie są jego uwarunkowania i efekty $\mathrm{w}$ środowisku rodzinnym $\mathrm{z}$ perspektywy młodych dorosłych $\mathrm{z}$ drugiego pokolenia polskich emigrantów w Niemczech? Celem analizy jest przedstawienie procesu wychowania dwujęzycznego, ze szczególnym uwzględnieniem procesu nabywania języka polskiego i wartościowania tego języka.

$\mathrm{W}$ badanej grupie młodych dorosłych z drugiego pokolenia polskich emigrantów w Niemczech wyraźnie dominuje dwujęzyczność niepełna - język polski jest przekazywany w ograniczonym zakresie w związku z używaniem go przede wszystkim w środowisku domowym, w kontekstach związanych z życiem codziennym. Przekazują go głównie rodzice (analiza zebranych danych pokazuje, że większy nacisk kładą na to matki). Ważną rolę w nabywaniu języka przez drugie pokolenie emigrantów odgrywają również dziadkowie i dalsza rodzina w Polsce. Uczestniczących w badaniach przedstawicieli drugiego pokolenia emigrantów w Niemczech cechuje najczęściej bilingwizm naturalny, wczesnodziecięcy i niezrównoważony.

Wszelkiego rodzaju kontakty z krajem pochodzenia wspierają motywację dzieci emigrantów do poznawania języka polskiego oraz sam proces jego nabywania. Więzi rodzinne z Polską, początkowo bardzo ścisłe, wraz z upływem lat się rozluźniają, a kontakty stają się mniej regularne i coraz słabsze. Badani młodzi dostrzegają, że dodatkowym utrudnieniem w ich podtrzymywaniu jest również brak odpowiedniej znajomości języka polskiego - kompetencje językowe badanych, wykształcone jedynie w środowisku rodzinnym, nie pozwalają na swobodną okazjonalną komunikację z rówieśnikami z Polski: „Mam koleżankę i kolegę w Polsce, co już znam [ich] od dzieciństwa [...]. Na początku łatwo się z nimi dogadywałam, [...] z czasem zaczęłam czuć, że słów mi brakuje" [W16 $\left.{ }^{27}\right]$.

Nieznajomość języka niemieckiego przez rodziców lub jedno z nich na pierwszym etapie emigracji często przekłada się na dbałość o rozwój kompetencji języka ojczystego u dziecka. Jak mówi jeden z badanych: „To był też mój pierwszy język, bo [rodzice] oni w ogóle nie mówili po niemiecku na

\footnotetext{
${ }^{27} \mathrm{~W}$ nawiasach kwadratowych podane są kody wywiadów, oznaczone literą W (wywiad) oraz liczbą porządkową.
} 
początku" [W13]. W takiej sytuacji młody człowiek przyjmuje komunikowanie się z bliskimi w języku polskim jako coś naturalnego. Dobrym przykładem będzie tutaj wypowiedź jednego z badanych, który opowiada o swoich odczuciach, kiedy ze względu na gościa, niemówiącego w języku polskim, rozmawiano w domu przy stole po niemiecku: „I to było dziwne dla nas, nieprzyjemne, żeby rozmawiać z mamą po niemiecku, bo to jest takie nie wiem - nienaturalne" [W1]. Jeden z ojców świadomie zataił przez dzieckiem znajomość języka niemieckiego, aby wymusić komunikację tylko po polsku. Badany wspomina swoją złość i zdenerwowanie w momencie, gdy - w wieku czterech lat - dowiedział się o tym [W13].

W przeprowadzonych wywiadach powtarzają się jednak wypowiedzi o zmieniającym się w rodzinie wraz z upływem czasu podejściu do obecności wyłącznie języka polskiego w domu. Jak mówi jeden z młodych migrantów, to poczucie ,normalności” stopniowo wypierane było też przez inne postawy: „wcześniej jak rodzice rozmawiali po polsku to normalnie było” [W5]. Jednak stopniowo - przy braku dążenia do pełnej dwujęzyczności i świadomej edukacji językowej również poza rodziną - język komunikacji domowej przekształcił się w kod mieszany, w razie potrzeby w domu wtrącało się zapożyczenia z języka niemieckiego. Badani mówią o „takiej mieszance między polskim a niemieckim”: „są frazy, w których albo sytuacje, w których mówimy więcej po polsku czy po niemiecku, to zależnie, ale raczej mieszano" [W17]. Wraz z upływem lat również rodzice, którzy wcześniej nie znali języka niemieckiego, uczą się tego języka, choć oczywiście z reguły ich poziom kompetencji językowych nie dorównuje poziomowi dziecka po kilku latach edukacji szkolnej w Niemczech. Wpływa to jednak na sposoby komunikowania się w środowisku domowym i sprzyja (chociażby okazjonalnemu lub jednostronnemu - po stronie dziecka) przechodzeniu na niemiecki.

Mieszanie języków i stopniowe przechodzenie przez rodziców w kontaktach z dzieckiem na język kraju osiedlenia w skrajnych przypadkach moga prowadzić do zaprzestania przez nie komunikacji w języku polskim. Można przypuszczać, że wielu rodzicom brakuje świadomości dotyczącej znaczenia pełnej dwujęzyczności dla dziecka z rodziny emigrantów oraz dla samej rodziny i jej funkcjonowania. W okresie, kiedy badani dorastali, dominujące w państwie niemieckim nastawienie asymilacyjne sprzyjało deprecjonowaniu wartości języka polskiego i powstawaniu wielu negatywnych mitów na temat samej dwujęzyczności. Dobrze oddaje to następująca wypowiedź: „Bo... różne ludzie mówili im, że oni [rodzice] muszą z nami po niemiecku, bo inaczej my nie będziemy mówić po niemiecku, my będziemy mieć problemy w szkole. To one zaczynali mówić po niemiecku i to ja też bardzo dużo i długo" [W13]. 
Wraz z wiekiem kompetencje w języku polskim dziecka wychowującego się $\mathrm{w}$ rodzinie emigrantów stają się niewystarczające do komunikacji z rodzicami na trudniejsze tematy. Ograniczony do spraw związanych z codziennym funkcjonowaniem zakres słownictwa przyczynia się do powierzchownej relacji między dzieckiem a rodzicami albo motywuje do podjęcia dalszych wysiłków w kierunku rozwijania kompetencji w języku polskim, albo też prowadzi do przejścia na komunikację w języku kraju osiedlenia, przynajmniej w rozmowach na trudniejsze tematy. Jeden z rozmówców opisuje to w następujący sposób: „Jak byłem już większy, to już nie rozmawiałem tyle po polsku, bo [pauza] bo mi się tak nie udało. Tematy były trochę bardziej cięż...ciężkie, to sobie poradziłem po niemiecku lepiej i [pauza], no ale nie wiem, my też zawsze tak mieszaliśmy, rozmawialiśmy po polsku i po niemiecku" [W3].

Uzupełnieniem domowej edukacji językowej bywa kształcenie w sobotniej szkole polonijnej, w której dziecko może poszerzyć zakres słownictwa poza codzienną komunikację oraz nauczyć się pisać i czytać po polsku. Dodatkowo szkoła sobotnia zapewnia też całej rodzinie dostęp do środowiska polonijnego, które może stanowić wsparcie w przekazywaniu języka, kultury i polskich tradycji oraz umożliwiać kontakty towarzyskie $\mathrm{w}$ języku polskim podczas pobytu na emigracji. Jeden $\mathrm{z}$ badanych wspomina również - poza szkółką polonijną - o polskim kościele jako miejscu spotkania z rówieśnikami polskiego pochodzenia, w którym rozmawiano po polsku [W2].

Tylko w kilku wypowiedziach pojawiła się opinia, że rodzice motywowali dziecko do nauki języka polskiego i je w tym wspierali. Badani częściej wspominają o tym, że raczej nikt ich nie motywował do nauki ojczystego języka, ale jednak - zwłaszcza we wczesnym dzieciństwie - w domu rozmawiano po polsku i utrzymywano kontakty z rodziną w Polsce. W kilku przypadkach do tych starań rodziców dochodzi jeszcze posyłanie dziecka do polonijnej szkółki sobotniej, traktowane przez młodych z rodzin emigrantów właśnie jako formę wspierania rozwoju ich kompetencji językowych. Można to zinterpretować jako bezrefleksyjne podejście rodziców do dwujęzyczności dziecka i przekazu języka ojczystego. Przekaz ten następował, ale najczęściej jedynie w podstawowym zakresie. Kiedy wygodniejsza była dla obu stron komunikacja w języku kraju osiedlenia, to automatycznie na nią przechodzono bądź też korzystano ze swobodnego mieszania języków w celu ułatwienia wzajemnego porozumienia, bez konieczności nabywania nowych kompetencji językowych.

W dwóch wywiadach pojawia się natomiast przykład ,rodziców motywujących", czy wręcz wymuszających na dzieciach pewne aktywności w celu utrzymania kontaktu z Polską, polską kulturą i językiem ojczystym. Jeden 
z badanych wspomina, jak rodzice czytali mu książki po polsku i wspólnie z nim oglądali polskie filmy [W19]. W innej rodzinie dbano o to, żeby rodzeństwo rozmawiało wyłącznie w języku rodzimym, co spotykało się $\mathrm{z}$ dużym oporem, jednak po upływie lat badany jest wdzięczny rodzicom, ponieważ dzięki ich naciskom umie obecnie mówić po polsku [W9]. Mamy w tych dwóch przypadkach świadome dążenie rodziców do przekazywania języka polskiego dzieciom.

Starania rodziców nie zawsze przekładaja się na motywację dzieci do nauki. Zdarza się, że dopiero w wieku nastoletnim doceniają one wartość znajomości języka polskiego. Wtedy pojawia się żal, że wcześniej nie były bardziej zaangażowane w naukę polszczyzny. Jeden z badanych przyznaje: „Ja teraz bardzo żałuję, że nie poszłem do polskiej szkoły, bo bardzo chętnie bym się nauczył, jak się pisze po polsku, bo to niestety w ogóle nie umię. Stosunek się polepszył do języka w wieku nastu lat" [W12]. Często łączy się to z nastoletnim poszukiwaniem własnej tożsamości, zgodą na przyznanie się do polskich korzeni, aż po ich akceptację, która jest świadomą decyzją.

Wydaje się, że mimo jakościowego charakteru badań i stosunkowo niewielkiej próby badawczej, można poczynić generalizację, dotyczącą dominującego bezrefleksyjnego podejścia rodziców do dwujęzycznego wychowania dzieci. Tak przynajmniej podejście to odbierają badani. Pewne starania są co prawda podejmowane, zwłaszcza w pierwszym okresie po przyjeździe do Niemiec. Rodziny decydują się na komunikowanie się w domu w języku polskim. Z upływem czasu coraz trudniej jest zachować ten jednorodny kod komunikacji, dochodzi do mieszania języków oraz posługiwania się językiem niemieckim, zwłaszcza przez dzieci, w celu lepszego wyrażenia swoich myśli w sytuacji braków leksykalnych w zakresie znajomości polskiego. Bez celowego podjęcia działań edukacyjnych rozwijających kompetencje dziecka w języku polskim, wykraczających poza rozmowę o sprawach życia codziennego, osiągnięcie przez nie pełnej dwujęzyczności wydaje się niemożliwe, co potwierdzają zebrane dane, jak również przegląd literatury przedmiotu. Tym samym ograniczona jest możliwość przekazu polskich tradycji, która umożliwiałaby młodemu człowiekowi z doświadczeniem migracji bycie aktywnym uczestnikiem polskiej kultury.

Rodzice niewątpliwie wpływają na stosunek dzieci do języka polskiego. Naturalne, spontaniczne wychowanie dwujęzyczne przekłada się w większości badanych przypadków na traktowanie języka polskiego jako środka komunikacji z rodziną, również z krewnymi w Polsce („,by porozumiewać się nim z rodziną polską" [W10]). Tym samym język ma przede wszystkim wartość komunikacyjną w środowisku rodzinnym, to ,,język rodziny”, jak określają to 
badani. Tylko w dwóch przypadkach pojawia się słowo „ojczysty” w odniesieniu do polskiego - przekaz języka mógłby pełnić tutaj również funkcję patriotyczną. Jeden z badanych wskazuje bezpośrednio na wartość tożsamościową polszczyzny. W jego odbiorze język polski ma wartość, ponieważ „moi rodzice pochodzą z Polski i dlatego, że język polski jest częścią mojej osoby" [W16].

Braki w zakresie znajomości języka polskiego przez dziecko moga przyczyniać się do podziałów w rodzinie, kiedy to porozumiewanie się w którymś z języków staje się narzędziem wykluczania bądź też okazjonalnego włączania jednego z rozmówców: „Rodzice mówią normalnie po niemiecku. Rzadko po polsku. Jak rodzice chcą, żebym coś zrozumiał, to przechodzą na niemiecki" [W12]. W kilku wywiadach pojawia się natomiast dowartościowanie języka polskiego przez badanych jako „tajnego języka rodziny”, umożliwiającego komunikowanie się między rodzicami a dzieckiem w kodzie niezrozumiałym dla otoczenia. Wydaje się, że ta dostrzeżona przez badanych funkcja języka pochodzenia, wykorzystana i świadomie rozwijania przez rodziców emigrantów, może sprzyjać budowaniu więzi rodzinnych, tożsamości rodziny i związku z Polską i polską kulturą. Wspólny kod komunikacji, odrębny od języka dominującego w otoczeniu, może jednoczyć rodzinę, przy założeniu, że w przypadku wszystkich jej członków jest to kod rozwinięty ${ }^{28}$.

\section{WNIOSKI I REKOMENDACJE PRAKTYCZNE}

$\mathrm{Na}$ podstawie przeglądu literatury przedmiotu, jak również analizy wyników badań własnych, można sformułować szereg wniosków oraz rekomendacji praktycznych w zakresie wspierania pełnej dwujęzyczności dziecka na emigracji, które będą mogły być wykorzystane nie tylko w odniesieniu do funkcjonowania rodzin polonijnych w Niemczech, ale w ogóle w sytuacji wychowywania dzieci na emigracji, zwłaszcza w krajach bardziej rozwiniętych gospodarczo niż Polska oraz z językiem o wyższym statusie społecznym (co jest charakterystyczne dla większości popularnych wśród Polaków celów migracyjnych).

Bez wątpienia dominująca strategia komunikacji językowej w rodzinie na emigracji (język polski, język kraju migracji czy też mieszanie języków) ma wpływ na sam proces wychowania i relacje między dziećmi a rodzicami.

\footnotetext{
${ }^{28}$ Por. Basil Bernstein, Odtwarzanie kultury (Warszawa: Wydawnictwo PIW, 1990).
} 
Omówione powyżej badania pokazały, że wraz z wiekiem dziecka pojawia się potrzeba porozumiewania się z rodzicem bardziej rozwiniętym kodem językowym. Potraktowanie języka polskiego, jako tego podstawowego kodu komunikacji w rodzinie, buduje więź między dziećmi a rodzicami, może być jednym ze źródeł tożsamości rodzinnej („tajemny język” rodziny) oraz umożliwia przekaz tradycji i kultury. Natomiast - jak słusznie zauważa Ewa Lipińska - ,przeniesienie punktu ciężkości na język kraju przyjmującego jest szkodliwe dla bilingwizmu i stwarza poważne zagrożenie dla znajomości języka ojczystego. Może to mieć przykre konsekwencje dla kultywowania polskości w ogóle, ale szczególnie w przypadku reemigracji" ${ }^{29}$. Wspieranie procesu nabywania kompetencji młodego pokolenia emigrantów w języku polskim pozwala zatem na przekaz kultury polskiej oraz otwiera w przyszłości przed nimi możliwość powrotu do kraju rodziców. Jednocześnie służy harmonijnemu rozwojowi tożsamościowemu, z uwzględnieniem poczucia polskości i akceptacją rodzimych korzeni, co pozwala na uniknięcie w wieku nastoletnim wielu problemów.

Jak się jednak okazuje, praktycznie niemożliwe jest osiągnięcie pełnej dwujęzyczności otwartej na kulturę kraju pochodzenia w sposób bezrefleksyjny, niejako „naturalny”, bez świadomych starań ze strony rodziców, wykraczających poza codzienną komunikację domową w języku polskim. Niezbędne wydają się celowe działania w zakresie wychowania dwujęzycznego, wyrównującego braki rozwoju językowego dziecka wynikające $\mathrm{z}$ funkcjonowania w środowisku emigracyjnym, w którym w sposób naturalny to język kraju przyjmującego staje się funkcjonalnie pierwszy i dominujący. Rodzic, podejmujący celowe i zaplanowane wysiłki w kierunku rozwijania kompetencji dziecka w języku polskim, staje się jednocześnie jego autorytetem w tym zakresie. Co prawda, wychowanie $\mathrm{w}$ rodzinie $\mathrm{z}$ reguły charakteryzuje się dużym stopniem spontaniczności i bezrefleksyjności ${ }^{30}$, jednak w przypadku wychowania dwujęzyczności niezbędny wydaje się świadomie przyjęty cel działań rodzicielskich oraz ich pewne zorganizowanie.

Wsparciem w przekazywaniu języka polskiego dzieciom polonijnym moga być również inni członkowie rodziny, przebywający zarówno w kraju pochodzenia (w pierwszej kolejności dziadkowie), jak i na emigracji (tj. środowiska polonijne zorientowane na edukację, przekaz obyczajów i tradycji, wzajemne

\footnotetext{
${ }^{29}$ Lipińska, Polskość w Australii, 163.

${ }^{30}$ Por. np. Andrzej W. Janke „Wychowanie rodzinne przedmiotem pedagogicznej refleksji”, w Pedagogika rodziny. Obszary i panorama problematyki, red. Stanisław Kawula, Józefa Brąiel, Andrzej W. Janke (Toruń: Wydawnictwo Adam Marszałek, 1998).
} 
wsparcie i kontakty towarzyskie). Obecnie nie do przeceniania wydają się ogólnie dostępne media w języku polskim, kanały telewizyjne, stacje radiowe, strony internetowe prezentujące dorobek polskiej kultury, wirtualne biblioteki, kanały na YouTube itp. Dużą pomocą mogłoby być oferowane rodzicom przez podmioty edukacyjne ( $\mathrm{w}$ tym reprezentujące środowiska polonijne) poradnictwo w zakresie dwujęzyczności ${ }^{31}$. Mimo tych licznych ułatwień wychowanie dwujęzyczne ukierunkowane na zrównoważoną dwujęzyczność wydaje się trudnym zadaniem, wymagającym wsparcia ze strony specjalistów, środowisk edukacyjnych czy też podmiotów polonijnych, zwłaszcza w przypadku emigrantów mieszkających w państwach z dominującą polityką asymilacyjną.

\section{BIBLIOGRAFIA}

Bernstein, Basil. Odtwarzanie kultury. Warszawa: Wydawnictwo PIW, 1990.

Besters-Dilger, Juliane, Anna Dąbrowska, Grzegorz Krajewski i Anna Żurek, red. Utrata i odzyskiwanie jezzyka polskiego. Jezykoznawcze i glottodydaktyczne aspekty niepetnej polsko-niemieckiej dwujezyczności. Łask: Oficyna Wydawnicza Leksem, 2016.

Błasiak, Marzena. Dwujęzyczność i ponglish. Zjawisko językowo-kulturowe polskiej imigracji w Wielkiej Brytanii. Kraków: Wydawnictwo Collegium Columbinum, 2011.

Cieszyńska, Jadwiga. Dwujęzyczność, dwukulturowość - przekleństwo czy bogactwo? O poszukiwaniu tożsamości Polaków w Austrii. Kraków: Wydawnictwo Naukowe Akademii Pedagogicznej, 2006.

Cieślińska, Barbara. „Niemcy bliskie i dalekie w świetle doświadczeń migracyjnych mieszkańców północno-wschodniej Polski”. Pogranicze. Studia Spoteczne 18(2011): 101-133.

Dębski, Robert. Dwujęzyczność angielsko-polska w Australii. Języki mniejszościowe w dobie globalizacji i informatyzacji. Kraków: Wydawnictwo Uniwersytetu Jagiellońskiego, 2009.

Dubisz, Stanisław. „Z metodologii badań języka środowisk polonijnych”. Poradnik Językowy 5(1983): 292-301.

Janke, Andrzej W. „Wychowanie rodzinne przedmiotem pedagogicznej refleksji”. W Pedagogika rodziny. Obszary i panorama problematyki, red. Stanisław Kawula, Józefa Brągiel, Andrzej W. Janke, 83-114. Toruń: Wydawnictwo Adam Marszałek, 1998.

Kainacher, Katarzyna. Dziecko w środowisku dwujezycznym i jego komunikacja międzykulturowa. Kraków: Wydawnictwo Collegium Columbinum, 2007.

Kawula, Stanisław. „Rodzina jako grupa i instytucja opiekuńczo-wychowawcza”. W Pedagogika rodziny. Obszary i panorama problematyki, red. Stanisław Kawula, Józefa Brągiel, Andrzej W. Janke, 47-82. Toruń: Wydawnictwo Adam Marszałek, 1998.

\footnotetext{
${ }^{31}$ Stankiewicz i Żurek. „Poradnictwo pedagogiczne w zakresie dwujęzyczności. Wsparcie rodziny na emigracji”, 161-175.
} 
Kowalcze-Franiuk, Karolina. Bilingwizm polsko-wtoski i tożsamość kulturowa emigracji okołosolidarnościowej. Kraków: Wydawnictwo Uniwersytetu Jagiellońskiego, 2018.

Lipińska, Ewa. Język ojczysty, język obcy, jezyk drugi. Wstęp do badań dwujęzyczności. Kraków: Wydawnictwo Uniwersytetu Jagiellońskiego, 2003.

Lipińska, Ewa. Polskość w Australii: o dwujęzyczności, edukacji i problemach adaptacyjnych Polonii na antypodach. Kraków: Wydawnictwo Uniwersytetu Jagiellońskiego, 2013.

Olpińska-Szkiełko, Magdalena. Wychowanie dwujezyczne w przedszkolu. Warszawa: Wydawnictwo Naukowe IKLA UW, 2013.

Pędrak, Agnieszka. „Wielowymiarowość dwujęzyczności dzieci (w kontekście emigracji)”. Społeczeństwo. Edukacja. Jezzyk 7(2018): 149-163.

Pułaczewska, Hanna. Wychowanie do jezyka polskiego w Niemczech na przykładzie Ratyzbony: dwujęzyczność dzieci z perspektywy rodziców. Łódź: Wydawnictwo Primum Verbum, 2017.

Ryszka, Łukasz. „Rola i znaczenie przekazu pokoleniowego w krzewieniu świadomości narodowo-kulturowej na przykładzie współczesnej Polonii w Niemczech”. Wychowanie w Rodzinie 9(2014), 1: 127-147.

Stankiewicz, Katarzyna i Anna Żurek. Ukryty program nauczania polskiego i niemieckiego jako języków obcych. Konteksty kulturowe. Łask: Oficyna Wydawnicza Leksem, 2014.

Stankiewicz, Katarzyna i Anna Żurek. „Poradnictwo pedagogiczne w zakresie dwujęzyczności. Wsparcie rodziny na emigracji”. W Poradnictwo rodzinne na emigracji. Teoria i praktyka, red. Józef Młyński, Władysław Szewczyk, 161-175. Warszawa: Wydawnictwo UKSW, 2021.

Stępkowska, Agnieszka. „Rodzinna polityka dwujęzyczności w Polsce na wybranym przykładzie”. Scripta Neophilologica Posnaniensia 17(2017): 329-343; https://doi.org/10.14746/snp. 2017.17.23.

Traktat między Rzeczypospolita Polska a Republika Federalna Niemiec o dobrym sqsiedztwie i przyjaznej wspótpracy, podpisany w Bonn dnia 17 czerwca 1991 r., Dz.U. 1992, nr 14, poz. 56.

Trzcielińska-Polus, Aleksandra, „Polska Misja Katolicka w Niemczech - jej rola w integracji środowiska polskiego". Ślaskie Studia Historyczno-Teologiczne 37(2004): 22-30.

Wróblewska-Pawlak, Katarzyna. Język, tożsamość, imigracja: o strategiach adaptacyjnych Polaków zamieszkatych we Francji w latach osiemdziesiatych XX wieku. Warszawa: Uniwersytet Warszawski, 2004.

Wróblewska-Pawlak, Katarzyna. „Naturalna dwujęzyczność, czyli o dwujęzycznym wychowaniu dzieci”. Jezyki Obce w Szkole 1(2013): 88-97.

Żurek, Anna. Strategie komunikacyjne osób dwujęzycznych. Na przykładzie polszczyzny odziedziczonej w Niemczech. Kraków: Towarzystwo Autorów i Wydawców Prac Naukowych Universitas, 2018.

Zdybicka, Zofia. „Analogia i partycypacja w wyjaśnianiu rzeczywistości”. W Analogia w filozofii, red. Andrzej Maryniarczyk, Katarzyna Stępień, Paweł Skrzydlewski, 91-100. Lublin: Polskie Towarzystwo św. Tomasza z Akwinu, 2005. 
WYCHOWANIE DWUJĘZYCZNE W RODZINIE POLONIJNEJ W NIEMCZECH. PERSPEKTYWA DRUGIEGO POKOLENIA EMIGRANTÓW

S t r e s z c z e n i e

Celem artykułu było przedstawienie procesu edukacji dwujęzycznej w rodzinie polonijnej mieszkającej w Niemczech na podstawie badań przeprowadzonych wśród dorosłych przedstawicieli drugiego pokolenia migrantów. Tło do prezentacji wyników badań stanowi omówienie specyfiki funkcjonowania rodzin polonijnych w Niemczech oraz podstaw teorii edukacji dwujęzycznej w ujęciu interdyscyplinarnym. Przegląd literatury przedmiotu oraz analiza wyników badań pozwala na sformułowanie rekomendacji w zakresie rozwijania pełnej dwujęzyczności dziecka oraz pielęgnowania relacji z kulturą polską i niemiecką poprzez odpowiednią edukację językową w domu.

Słowa kluczowe: wychowanie dwujęzyczne; dwujęzyczność; rodzina polonijna w Niemczech; emigracja; język polski. 